\title{
UVOD U TRADICIJSKO GOSPODARSTVO
}

\author{
Marijeta RAJKOVIĆ \\ Filozofski fakultet Sveučilišta u Zagrebu \\ Odsjek za etnologiju i kulturnu antropologiju \\ Ivana Lučića 3, 10000 Zagreb
}

$\mathrm{P}$ rimarni izvori prihoda najvećeg dijela Krivopućana bili su stočarstvo i zemljoradnja. No ove dvije grane nikako nisu bile dostatne za prehraniti obitelj, stoga su muškarci nerijetko pronalazili dodatne izvore prihoda odlaskom na privremene radove na prostore Slavonije, zapadne Europe ili na višegodišnje odlaske u Ameriku ili Kanadu. Krivopućani, Podbilari, Alanari kao i većina muškaraca koji su stalno živjeli u zaselcima smještenim na primorskoj strani Velike Kapele od oko 500 metara nadmorske visine preko zime radili su kao šumski radnici. Primorci su tijekom godine radili kao zidari i kamenari. Tvornica nije bilo, nije bilo ceste, struje, jako je bio surov život. Teško je bilo prehranit obitelj, ljudi su svaštarili. Išlo se pješke u Senj, popriko 13-14 km, a okolo cestom $17 \mathrm{~km}$... ako su trebali namirnicu, pješke nosi na ledima. Neimaština je natjerala ljude da su se počeli masovno iseljavat. Jednu večer sam se prisjetio kuća na kojima su bili krovovi dok sam ja bio dijete, pa sam nabrojio 70 kuća. Za neke se danas ne znaju ni temelji, kazao je Milan Blažević Ivela iz Mrzlog Dola.

Pojedinci su bili samouki obrtnici. Na Krivome Putu bilo je stolara, tesara, kovača, neki su dodatne izvore prihoda stjecali proizvodeći i prodajući japno (vapno) i sl.

Obitelji su imale volove ili konje. Razlog zašto je netko imao konje, a netko volove uvjetovala je površina obradivoga zemljišta, geografske odlike terena, te imovinsko stanje obitelji. Na Alanu su imali dvije vrste konja budući da se većina muškaraca bavila kirijom (izvlačili iz šume drva i klade). Nakon Drugoga svjetskog na Alanu je otvorena pilana na kojoj je radilo mnogo Krivopućana, ali i ljudi iz okolnih područja.

Dodatni izvori prihoda bile su i ilegalne trgovine drvima raširene na širem području Velebita, ${ }^{1}$ pa tako i ovdje. Kazivači o tome otvoreno govore jer, kažu, gotovo svi su to radili. Moj otac je prodava drva na vozove i od tog smo živjeli. Mora si lugaru platiti, propusnicu (smijeh) ako si tia drva prodavat. Moj stari ti je ukra u šumi ko letve, gredice. E, a u Senju je bio drugi lugar i ovaj mu zaplini, istovari na moru. To je bilo na Mali vrati. Onda je moj stari čeka da lugar ode, iza podneva, pa proda bodulima (stanovnici otoka). Sićeš drva u šumi, tovariš, voziš, platiš lugaru $i$ kad dodeš do Senja drugi lugar ti zaplini. Tako se dosta dogadalo. A nije bilo lako².

Unatoč tome što bi se svaka od spomenutih djelatnosti mogla detaljno istražiti svoj zadatak usmjerila sam na šest priloga: selidbe i suživot na ljetnim stanovima, stočarstvo, sjenokošu, zemljoradnju, pčelarstvo i lov na divlje životinje. Istraživanje za sve teme provedeno je na području Krivoga Puta. Pod područjem Krivog Puta smatram sva naselja koja su mu tijekom 20. stoljeća gravitirala (ondje se nalaze trgovina i osnovna škola), dakle u Primorju od Sibinja, Bunice, Sv. Jelene, Pijavice, preko Vrataruše, Kosove Buljime, Šušnja, Klaričevca, Francikovca, Šojatskoga Dolca, pa do samog mjesta Krivi Put, Podbila, Alana, Mrzloga Dola i Veljuna. Kako bih prikazala kompleksnost života na području Krivoga Puta, te ukazala na razlike u tradicijskom gospodarstvu s obzirom na nadmorske visine, ovaj prilog započinje prikazom selidbi na ljetne stanove i života domicilnog i migratornog stanovništva.

Zabilježila sam podatke da su se takvom trgovinom bavile i žene na području Senjskoga bila (usp. M. Rajković, 2003: 570).

2 Ova zanimljiva tema ostaje za neka daljnja istraživanja. Budući da sam zabilježila velik broj ovakvih priča, odlučila sam ne navesti ime kazivača. 
Građa je sakupljena tehnikama intervjua u više navrata od 2003. do 2006. godine. Svi prilozi kronološki pokrivaju razdoblje 20. stoljeća, te se, kada je to bilo moguće prema sjećanjima Krivopućana, zahvatio i kraj 19. stoljeća. Najviše građe prikupljeno je do sedamdesetih godina 20. stoljeća budući da se stanovništvo iseljavalo iz Krivoga Puta i pronalazilo nove izvore prihoda.

$\mathrm{Na}$ Krivoputskome području prema mojim saznanjima, do sada nitko nije istraživao tradicijsko gospodarstvo. Kao polazišna pitanja poslužila su pitanja navedena u Upitnici Etnološkog atlasa (u daljnjem tekstu UEA), svezak prvi. Pitanja su prilagođena ovom području i pojedinim kazivačima. Intervjui su provedeni prema Dorsonovoj klasifikaciji, prema kojoj se usmena osobna povijest odnosi na osobnu povijest i iskustvo pojedinaca (razgovarala sam s Krivopućanima koji su osobno selili na ljetne stanove, bavili se lovom na divlje životinje ili pčelarili), te na usmenu tradicijsku povijest koja je zajednička cijeloj zajednici ${ }^{3}$. Na pojedine teme svi kazivači davali su iste odgovore. No da se neki opisi vjerodostojnije prikažu objasnila sam ih citirajući Krivopućane. Odabir koga ću citirati bio je slučajan, uglavnom osoba s kojom sam prvom razgovarala o toj temi, osoba kojoj je neka tema ostala u najdetaljnijem sjećanju i sl. U takvim primjerima nakon podatka o kazivaču, navedeno je da su isto potvrdili svi ostali kazivači. Ponekad je razgovoru prisustvovalo nekoliko kazivača, te se katkada prilikom transkribiranja nije moglo odvojiti njihova kazivanja ili su se kazivači međusobno nadopunjavali. U takvim primjerima kod citiranja svi su navođeni.

Podatke s terena, kada je to bilo moguće, dopunilo se podacima iz popunjenih upitnica UEA koje se čuvaju u Arhivu Etnološkog atlasa na Filozofskom fakultetu u Zagrebu. Međutim za sve navedene lokalitete postoji jedna upitnica za mjesto (selo) Krivi Put (pod signaturom Fd 241, rednim brojem 1382) stoga su podaci u njima generalizirani geografski i kronološki, uglavnom vrlo pojednostavljeni. Naime, istraživanja za Etnološki atlas provođena su šezdesetih godina 20. stoljeća, a moja četrdeset godina kasnije. Upitnicu nije popunjavalo etnolog i vjerojatno stoga, unatoč vremenskoj razlici početkom 21. stoljeća, zabilježeni su detaljniji opisi za pojave za koje je u Upitnici navedeno da ne postoje, primjerice teme iz lova na divlje životinje, pčelarstva i sl.

Osim prikaza tradicijskoga gospodarstva, cilj ovih priloga je potaknuti potomke i lokalnu zajednicu na današnju gospodarsku mogućnost iskorištavanja područja Krivoga Puta te na njegovu revitalizaciju.

3 Više o usmenoj povijesti vidi u: DORSON, Richard: The Oral Historian and the Folklorist. U: ur. Dunaway, David K., Baum, Willa K.: Oral History, an interdisciplinary Anthology, Altamira press, Walnut Creek, Lanham, New York, Oxford, 1996., str. 289. 